\title{
Percent Inhibition
}

National Cancer Institute

\section{Source}

National Cancer Institute. Percent Inhibition. NCI Thesaurus. Code C117963.

The rate of measured normal activity minus inhibited activity, divided by the rate of normal activity of a given object. It is expressed as a percentage. 